\title{
The disappearing immigrants: hunger strike as invisible struggle
}

\author{
Ally Walsh ${ }^{1}$ and Myrto Tsilimpounidi ${ }^{2}$
}

This article invites readers to consider an act of civil resistance as a performative one. A large scale hunger strike conducted by 300 immigrants in central Athens in early 2011 became a catalyst for Greek conversations about civil society. In particular, the strike offered supporters the opportunity to engage more widely with debates on immigration and human rights across Europe, alongside reading the virulent effects of the economic crisis in financial capital terms and resulting neo-liberal backlashes. The authors employ a performative frame; initially the context of Athens is explored as the stage primed for a performance. Secondly, the value of the Law School as site for the hunger strike is considered, with specific reference to Lefebvre's spatial resistance. The hunger strike itself is analysed as a 'performance of resistance', and as a spectacle. The audience is considered a witness to the act, reflecting their moral imperative to react to the 'performance'. Finally, the wider social, political and cultural implications of such a hunger strike are considered. Throughout, we are concerned with the invisible bodies of the hunger strikers, particularly regarding how their struggle is represented or appropriated. [Article copies available for a fee from The Transformative Studies Institute. E-mail address: journal@transformativestudies.org Website: http://www.transformativestudies.org (02012 by The Transformative Studies Institute. All rights reserved.]

KEYWORDS: Hunger Strike, Immigration, Greece, Resistance, Performance.

\footnotetext{
${ }^{1}$ Ally Walsh is currently pursuing a $\mathrm{PhD}$ in Theatre Studies (provisional title: Performing (for) Survival), with 10 years' experience in criminal justice settings, a background in theatre making, education and facilitation and an ongoing interest in using theatre in social and community contexts.

${ }^{2}$ Myrto Tsilimpounidi is executive director of Ministry of Untold Stories, an activist and social researcher. Myrto is completing a PhD in Social and Political Thought (title: Re-Mapping Athens: A View of the Cosmopolitan Milieu through Festivals). Her background is in economics and development studies, and critical global studies. Forthcoming publications include a chapter in European festivals. Address correspondence to: Ally Walsh, University of Northampton, St George's Avenue, Northampton, UK NN2 6JD; e-mail: aylwynwalsh@northampton.ac.uk.
} 